\section{EFFECT OF STOCKING DENSITY ON THE GROWTH PERFORMANCE OF RED TILAPIA IN ZEOLITE SUPPLEMENTED CLOSED SYSTEM}

\author{
Ku Boon Hong, Musfiroh Jani*, Rabiatul Adawiyah Meor Mohamad \\ Zain, Norashikin Mohd Fauzi
}

Faculty of Earth Sciences University Malaysia Kelantan, UMK Jeli Campus, Jeli, Kelantan Malaysia
Article history

Received

9 June 2021

Received in revised form

27 July 2021

Accepted

4 August 2021

Published online

20 August 2021

*Corresponding author musfiroh@umk.edu.my

\section{Graphical abstract}

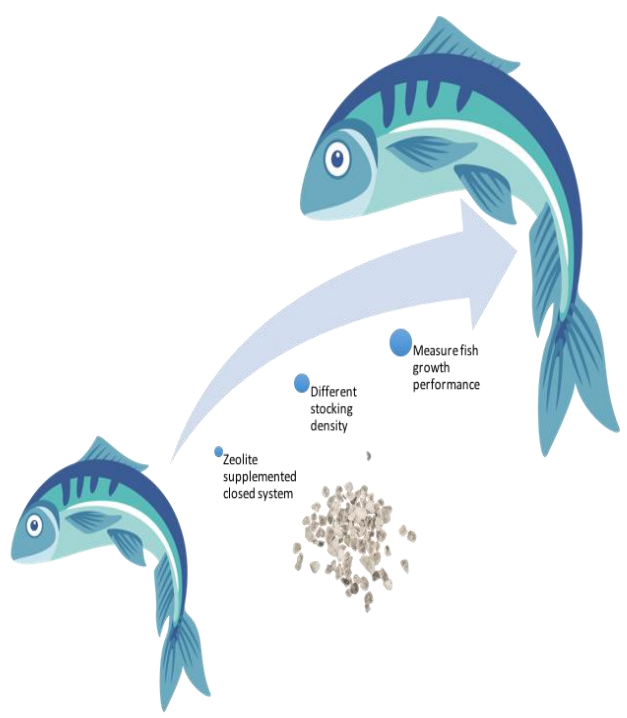

\begin{abstract}
Food demand is expected to surge due to the increase of world population. Malaysia is one of the top fish consumption countries in Asia, but the reduction of capture fishery has led to the increase for aquaculture for tilapia to overcome the demand. Thus, the objective of this study was to compare the growth performance of red tilapia at different stocking densities of zeolite supplemented closed system. Red tilapia fry was stocked into aquarium. Five treatments (containing zeolite and without zeolite) with two replicates were used. Food was given twice a day with $2 \%$ of total biomass of the fish. Weight and length of red tilapia were measured every two weeks. The zeolite treatments which recorded the highest final mean weight was $\mathrm{Tl}$ with the lowest stocking density (5 fish) while in T5 (highest stocking density), lowest mean weight was recorded. Specific growth rate and length gain in $\mathrm{Tl}$ was significantly higher than other treatments. On the other hand, there was no significant difference in growth parameters between the treatments with and without zeolite. The results revealed that red tilapia stocked in the $\mathrm{Tl}$ of the lowest stocking density ( 5 fish) had the highest growth performance than the fish in other treatments. Compared to other treatments, Tl recorded the highest final length and weight, weight and length gain, Specific Growth Rate \% (SGR) among the treatments. The findings will be useful for the practitioners to understand the best practice for stocking density in zeolite supplemented closed system.
\end{abstract}

Keywords: Closed-system, Red tilapia, Stocking density, Zeolite, growth performance

\begin{abstract}
Abstrak
Permintaan makanan dijangkakan melonjak disebabkan oleh kenaikan populasi dunia. Malaysia merupakan salah satu negara yang tertinggi di Asia yang mengambil ikan sebagai makanan. Walaubagaimanapun, pengurangan penangkapan ikan melalui perikanan menyebabkan peningkatan akuakultur tilapia untuk mengatasi permintaan. Oleh itu, objektif kajian ini adalah untuk membezakan prestasi pertumbuhan ikan tilapia merah pada ketumpatan stok yang berbeza dalam sistem tertutup dengan tambahan zeolite. Anak ikan tilapia merah dimasukkan ke dalam akuarium. 5 rawatan (mengandungi zeolite dan tidak mengandungi zeolite) dengan dua replikat telah digunakan. Makanan diberikan dua kali sehari dengan $2 \%$ dari jumlah biojisim ikan. Berat dan panjang ikan tilapia merah diukur setiap dua minggu. Selepas 9 minggu, rawatan zeolit yang mencatatkan bacaan tertinggi berat akhir adalah $\mathrm{Tl}$ (ketumpatan stok yang terendah) manakala T5 (ketumpatan stok tertinggi), mencatatkan berat min terendah..Kadar pertumbuhan spesifik dan kenaikan panjang dalam $\mathrm{Tl}$ adalah tertinggi secara signifikan berbanding rawatan yang lain. Manakala, tiada perbezaan
\end{abstract}


signifikan dalam parameter pertumbuhan antara rawatan yang mempunyai zeolit dan tanpa zeolit. Keputusan menunjukkan bahawa tilapia merah dengan stok $\mathrm{Tl}$ iaitu stok yang mempunyai ketumpatan stok terendah (5 ikan) mempunyai pertumbuhan tertinggi berbanding rawatan lain. T1 mencatatkan berat dan panjang tertinggi, kenaikan berat dan panjang, SGR berbanding rawatan lain. Penemuan ini berguna bagi pengamal untuk memahami amalan terbaik bagi ketumpatan stok dalam sistem tertutup yang disokong oleh bahan zeolite.

Kata kunci: Sistem tertutup, tilapia merah, ketumpatan stok, zeolit, prestasi pertumbuhan.

(C) 2021 Penerbit UTM Press. All rights reserved

\subsection{INTRODUCTION}

According to United Nations Department of Economic and Social Affairs, the food demand is expected to increase by $70 \%$ by 2050 due to population growth. Most of the population will exist in developing countries where living standards are rapidly rising, and food needs such as meat and dairy products will increase to meet basic dietary needs. The current production of 1.3 billion tons of food is not enough to meet people's needs in 2050. Asia is the developing country with two-thirds of the hungriest nation. Developing countries are the nations with the highest fish consumption. Food and Agriculture Organization (FAO) showed that Malaysia is one of the top fish consumption countries in Asia which is double the average in China and Thailand. The tilapia is the world second important farmed fish species in the world after carps and they are typically farmed in tropical, subtropical and temperate regions. They are primarily cultured in the freshwater farmed, rice fields and in tanks (glass, concrete or plastic). The large-scale farming of red tilapia in Malaysia is due to its favorable characteristics; high growth rate, tolerates a wide range of temperatures and dissolved oxygen, has a high resistance to diseases, and is highly acceptable in the market [1]. In 2018, the production of red tilapia and black tilapia in Malaysia contributes to highest of total freshwater aquaculture production at 30.7\% [2]. However, this figure clearly shows that the high potential of red tilapia farming has not yet been fully utilized and shows some challenges that need to be addressed. The three most important Tilapia species in aquaculture industry are Oreochromis niloticus, Oreochromis mossambicus, and Oreochromis aureus [3]. Tilapia is suitable for blackish water and seawater culture due to its salt tolerance characteristics. The tilapia species cultivated mainly by fisherman in Malaysia is red tilapia because the red tilapia has a higher price than Nile tilapia in the market. The high price and demand of red tilapia is because its red coloration is favored by people, especially the Chinese [2]. In Malaysia, cages culture of red tilapia in freshwater dams, former mining pools, rivers, irrigation canals and reservoirs using the semiintensive and intensive method are practiced [4-5].
Advantages of cages culture system are it requires low capital investment and has high flexibility of management compared to ponds and tanks. On the contrary, tank culture requires high capital investment because of high construction and production costs (complete commercial diet, aeration, recycling system). Tank culture of tilapia also poses a higher risk of major fish mortality due to disease outbreaks and electrical failures [6]. Stocking density is an important factor in ensuring optimal fish productivity because it is directly related to physiological, physical and chemical parameters such as growth rate, water quality, physiological ability, nutrient and culture system type, and biochemical stage [7-8]. Recently, the effect of stocking density was studied in new technology involving aquaponic system integrated with plant and extensive pond systems [9]. Thus, the main objective of this study is to determine the effect of stocking density $(5,10,15,20$, and 25 fry/aquarium), on water quality and growth parameters of fresh water aquarium fish, red tilapia, Oreochromis niloticus, at different stocking density supplemented with zeolite. Zeolites are microporous crystalline hydrated aluminosilicates, which are found in various applications because of their unique physicochemical characteristics such as ion exchange and adsorption-desorption properties [10]. It has been known for its efficiency in removing toxicity from freshwater systems [11-14]. Natural and synthetic zeolite was used previously in different fish species pond and hatchery [15-24]. This study also aimed to compare the growth performance of fish in treatments with and without zeolite. This study has been carried out in Universiti Malaysia Kelantan, Malaysia in 2019.

\subsection{METHODOLOGY}

225 fry of red tilapia were distributed to 15 aquariums containing 30 liters of tap water and acclimatized for two weeks. After the acclimation period, 5 fry of red tilapia were placed in an aquarium containing 30 liters of tap water (Figure 1). Tap water is a municipal water supply containing chlorinated water. In order to make the water harmless to the fish, 0.5 grams of 
anti-chlorine crystals are added to each aquarium to remove chlorine or chloramine from the tap water. 450 grams of zeolite granule were then placed in a non-woven fabric drain filter and suspended in the water column. Clinoptilolite is used as adsorbent for pollutants in the aquariums. Thereafter, the aquarium is supported by an aerator diffuser to circulate water. The circulation helps to keep the water in the aquarium well oxygenated by moving water from the bottom to the surface to pick up oxygen and release carbon dioxide. Another four treatments with fish densities of $\mathrm{T} 2=10, \mathrm{~T} 3=15, \mathrm{~T} 4=20$ and $\mathrm{T} 5=25$ were prepared using the same method. All treatments were duplicated to reduce errors during the measurement. Next, a control treatment for each stocking density without zeolite was prepared. Fishes was fed a commercial feed containing $35 \%$ crude protein twice daily for 9 weeks.

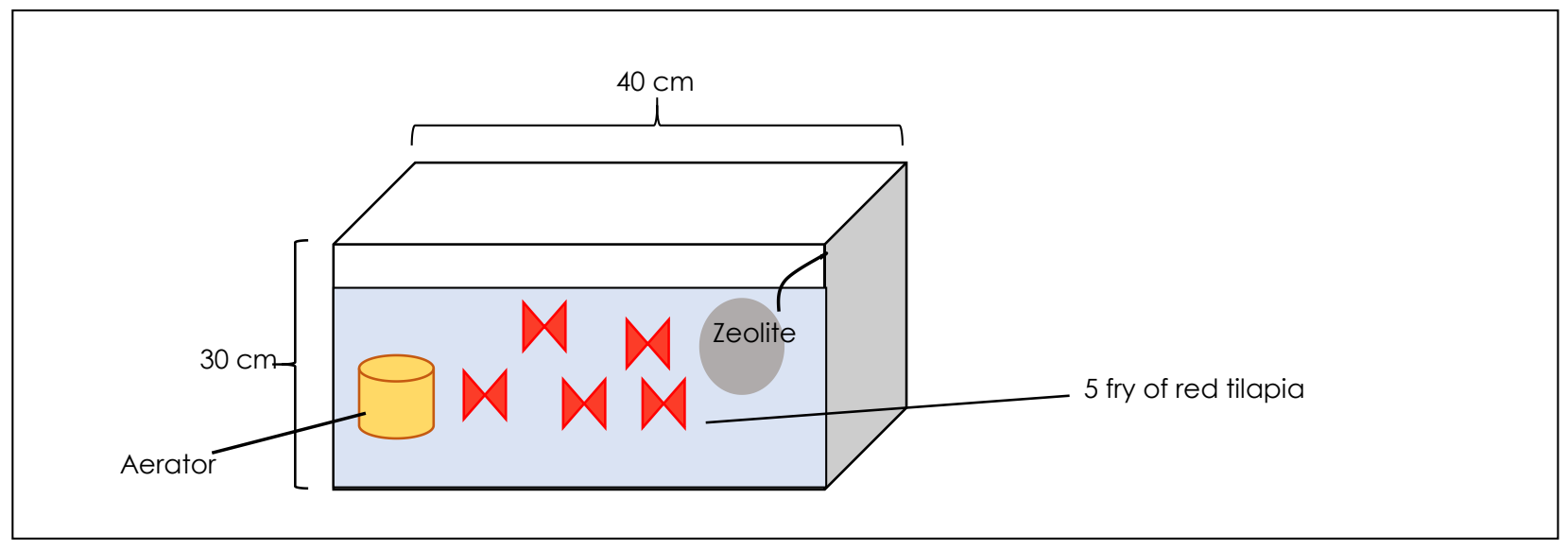

Figure 1 Aquarium set-up containing red tilapia and supplemented with zeolite

\subsection{Fish Feeding and Culture}

The fishes were fed with $2 \%$ of their body weight twice (at 9 am and $5 \mathrm{pm}$ ) a day at 8 hour interval for 63 days. The amount of feed was adjusted according to average weight of the fish in each aquarium. The remaining feed and feces in each aquarium are cleaned once a week. The water in each aquarium is replaced with pre-treated pipe water every week. On the other hand, daily inspections are also carried out to remove dead fish.

\subsection{Fish Sampling}

The fish in each aquarium was randomly selected, weighed and released back to the aquarium every two weeks. During the sampling process, $15 \%$ of the stocked fish from each aquarium was scooped out with a scoop net. After drying with a towel, their weight and length is measured. In the eighth week, the weight and length of all fish in the aquarium were measured. The number of fish was also calculated at the end of the experiment.

\subsection{Data Collection and Analysis}

The weight and length of the fish in each aquarium were measured every two weeks using electronic scale and vernier calipers. The measurement of weight was used to determine to evaluate the growth performance of red tilapia by calculating the SGR (\%), WG (\%), length gain (LG) and ADWG of fish in each aquarium (Eqs. 1-4). Survival rate (\%) was also calculated by determining the number of fish in each aquarium at the end of the experiment (Eq. 5).

$$
\begin{aligned}
& \text { Specific Growth Rate, SGR (\%) } \\
& =100\left[\left(\ln W_{t}-\ln W_{0}\right) / t\right] \\
& \text { Weight Gain, WG (\%) } \\
& =100\left(W_{t}-W_{0}\right) / W_{0} \\
& \text { Length Gain, LG }(\mathrm{mm}) \\
& =L_{t}-L_{0}
\end{aligned}
$$

$=\left(W_{t}-W_{n}\right) / t$

Survival Rate, SR (\%)

$=$ (Final number of fish/ Initial number of fish) $\times 100(5)$

Where $W_{\dagger}$ and $W_{0}$ are final and initial weight $(g)$, and $t$ is time in days from stocking to harvesting.

\subsection{Statistical Analysis}

All data collected were subjected to statistical analysis and analysed by using SPSS version 20 program. Two-way analysis of variance (MANOVA) was used to evaluate the effects of stocking densities on water quality and the growth performance of red tilapia in zeolite supplemented closed system at the five stocking densities. In addition, MANOVA was used to analyze the effect of zeolite on water quality and growth performance of fish between treatments 
with and without zeolite. Then, a post hoc test using Tukey's multiple range tests, with $\mathrm{p}<5 \%$ significance levels were used to evaluate the differences among treatment means.

\subsection{RESULTS AND DISCUSSION}

3.1 Effect of stocking density on growth performance of red tilapia in zeolite-containing treatments

The growth performance of red tilapia in different treatments in terms of initial number and final mean number (n), mean weight, mean length, weight gain (WG), length gain (LG), average daily weight gain (ADWG), specific growth rate (SGR), and survival rate (SR) were calculated and are presented in Table 1. The effect of stocking density on growth performance of red tilapia was investigated in the experiment.

\subsection{Length and Weight}

At the beginning of the experiment, there was no

significant difference ( $p>0.05$ ) in initial weight and length of red tilapia under different treatments.
Significant difference $(\mathrm{p}<0.05)$ were observed among five treatments in final mean length and weight when compared using MANOVA. The results showed that with the increase of stocking density, the final mean length and weight showed a downward trend. It was found that fry stocked in $\mathrm{Tl}$ exhibited the highest mean final length and weight (106.33 and 40.27) while fry stocked in T5 recorded the lowest (87.83 and 17.26). The final mean weight and length observed at high stocking density were low; this may be due to insufficient acquisition of feed, low availability of oxygen and increased competition for food and the space for fish movement. These results are in agreement with the findings obtained by Chakarborty and Banerjee, who revealed that the increased fish biomass of Nile tilapia in cages had a significant negative effect on the final mean weight [25]. Ferdous et al., reported that Monosex tilapia in hapa at a low density had a better growth than at a higher density [26]. The lower growth performance of tilapia at higher stocking density may be caused by voluntary appetite suppression, more energy is expended on intense antagonistic behavioral interaction between fish, increased competition for food and living space, and increased stress due to reduction in space availability [26].

Table 1 Growth parameters (mean \pm SD) of red tilapia in the zeolite treatments at different stocking densities

\begin{tabular}{|c|c|c|c|c|c|}
\hline Growth Parameters & T1 & T2 & T3 & T4 & T5 \\
\hline Initial number (n) & 5 & 10 & 15 & 20 & 25 \\
\hline Final mean number $(n)$ & $3.5 \pm 2.12$ & $8.5 \pm 2.12$ & $14.5 \pm 0.71$ & $19 \pm 1.41$ & $23 \pm 1.41$ \\
\hline Mean initial weight $(g)$ & $12.90 \pm 0.01$ & $12.90 \pm 0.01$ & $12.90 \pm 0.01$ & $12.90 \pm 0.01$ & $12.90 \pm 0.01$ \\
\hline Mean final weight (g) & $40.27 \pm 15.84^{b}$ & $23.17 \pm 0.7^{a b}$ & $21.47 \pm 0.00^{a b}$ & $19.63 \pm 2.18^{a b}$ & $17.26 \pm 0.15^{a}$ \\
\hline Weight gain, WG (\%) & $212.17 \pm 122.78^{a}$ & $79.65 \pm 5.43^{a}$ & $66.43 \pm 0.00^{a}$ & $52.17 \pm 16.88^{a}$ & $33.76 \pm 1.15^{a}$ \\
\hline Length gain (mm) & $24.38 \pm 2.46^{b}$ & $15.38 \pm 5.44^{\mathrm{ab}}$ & $11.18 \pm 0.33^{a b}$ & $8.71 \pm 4.63^{a}$ & $5.88 \pm 2.01^{a}$ \\
\hline $\begin{array}{l}\text { Average daily weight } \\
\text { gain, ADWG (g) }\end{array}$ & $0.4345 \pm 0.2541^{a}$ & $0.1631 \pm 0.0112^{a}$ & $0.1360 \pm 0.0000^{a}$ & $0.1069 \pm 0.0346^{a}$ & $0.0692 \pm 0.0023^{a}$ \\
\hline $\begin{array}{c}\text { Specific growth rate, SGR } \\
\text { (\% per day) }\end{array}$ & $1.74 \pm 0.64^{b}$ & $0.93 \pm 0.05^{a b}$ & $0.81 \pm 0.00^{a b}$ & $0.66 \pm 0.17^{a b}$ & $0.46 \pm 0.01^{a}$ \\
\hline Survival rate, SR (\%) & $70 \pm 42.43^{a}$ & $85 \pm 21.21^{a}$ & $96.67 \pm 4.72^{a}$ & $95 \pm 7.07^{a}$ & $96 \pm 5.66^{a}$ \\
\hline
\end{tabular}

\subsection{Specific Growth Rate}

In the current study, there was a significant difference $(p<0.05)$ in specific growth rate (SGR) between the five treatments. As can be seen from Table 1, the mean specific growth rate of red tilapia in different treatments was between 0.46 and 1.74.
The significantly $(p<0.05)$ highest SGR values (1.74) was recorded in $\mathrm{Tl}$ while the lowest (0.46) was recorded in $\mathrm{T} 5$. The low growth rate in $\mathrm{T} 5$ may be due to increased crowding effect of fish, making it difficult for the fish to move to reach the food, thus reducing the feeding rate. It can be seen that it is more difficult to ensure uniform distribution of food at high 
stocking densities. These results are consistent with the results obtained by Dambo and Rana [27], who reported that SGR was significantly affected by stocking density.

\subsection{Weight Gain and Length Gain}

The final mean weight gain of red tilapia in different treatments ranged between 33.76 and 212.17. The weight gain of fish was statistically similar $(p>0.05)$ at different stocking densities (Table 2). The highest and lowest final weight gain of red tilapia was recorded in T1 (212.17) and T5 (33.76) respectively. The final length gain of individual fish in different treatments ranged between 5.88 and 24.38. There was a significant difference $(\mathrm{p}<0.05)$ at different stocking density (Table 2). The length gain of red tilapia in T1 (24.38 \pm 2.46$)$ was significantly highest and in T5 (5.88 \pm 2.01$)$. The low growth at high stocking densities may be due to social interaction through competition for food and living space; this may lead to increase stress, resulting in increased energy demand and decreased in weight gain. Similar observations were made by Ofor and Afia who found that the weight gain of hybrid catfish was not affected by stocking density [28]. The weight gain and length gain in $\mathrm{Tl}$ higher than all others, it can be assumed that there is metabolic savings and low energy consumption at this density. These findings were similar to those reported by Rahman, who revealed that the Monosex male tilapia stocked at the lowest densities achieved optimal weight gain [29].

Table 2 Overall comparison of specific growth rate (SGR), weight gain (WG), survival rate (SR), and length gain (LG) between different treatments with zeolite. Mean difference is significant at the 0.05 level. Mean were tested by ANOVA and ranked by Tukey's multiple range tests

\begin{tabular}{|c|c|c|c|c|c|c|c|}
\hline Source & $\begin{array}{l}\text { Depend } \\
\text { ent } \\
\text { Variabl } \\
\text { e }\end{array}$ & $\begin{array}{l}\text { Type III } \\
\text { Sum of } \\
\text { Squares }\end{array}$ & df & $\begin{array}{l}\text { Mean } \\
\text { Square }\end{array}$ & $\mathbf{F}$ & Sig. & $\begin{array}{l}\text { Partial } \\
\text { Eta } \\
\text { Square } \\
\text { d } \\
\end{array}$ \\
\hline \multirow{4}{*}{ Treatment } & $S G R$ & 1.939 & 4 & .485 & 5.418 & .046 & .813 \\
\hline & WG & $\begin{array}{l}40350.89 \\
7\end{array}$ & 4 & $\begin{array}{l}10087.72 \\
4\end{array}$ & 23.277 & .113 & .724 \\
\hline & $S R$ & 945.452 & 4 & 236.363 & .502 & .738 & .287 \\
\hline & LG & 415.135 & 4 & 103.784 & 8.467 & .019 & .871 \\
\hline
\end{tabular}

\subsection{Survival Rate}

In this study, there was no significance ( $>>0.05)$ different in survival rate between treatments (Table 2). Tukey's test showed that there was no significant different in survival rate between $\mathrm{Tl}$ and the rest of the treatment. The results showed that survival rate for all the treatments were above $70 \%$. Fish reared in T3 recorded the highest percent survival of $96.67 \%$ while the fish population reared in $\mathrm{Tl}$ showed the lowest percent survival of $70 \%$. It can be seen that survival rate did not show a significant decline as stocking density increased. This may be because the stocking density is not as high as that commonly used in aquaculture. The stocking densities have not reached the threshold at which food availability and competition among individuals impacted growth rate. These results are in agreement with Rahman who reported that the mortality of Nile tilapia in cages was not dependent on stocking density [29]. The results of current study showed that, survival rates increase with high stocking density. Similar results were obtained by Ouattara et al., who showed $98 \%$, $96 \%$ and $100 \%$ survival rates $\left(50 \mathrm{fish} / \mathrm{m}^{3}, 100 \mathrm{fish} / \mathrm{m}^{3}\right.$ and $\left.150 \mathrm{fish} / \mathrm{m}^{3}\right)$ [30]. The lower survival rate in $\mathrm{Tl}$ could be attributed to the inhibition of proper feeding of smaller fish due to the presence of larger fish. Consequently, the high survival rate of red tilapia at high stocking density in this study showed the ability of to survive in poor conditions (including high density) and the amenability of this fish to the intensive culture system.

In general, the growth performance of red tilapia in zeolite systems decreased as the stocking density of fish increased. Based on the growth performance parameters recorded in this study, it was found that red tilapia stocked in the Tl of the lowest stocking density (5 fish) had the highest growth performance than the fish in other treatments. Compared to other treatments, $\mathrm{Tl}$ recorded the highest final length and weight, weight and length gain, SGR among the treatments. As conclusion, T1 with the lowest fish density is the most suitable stocking density for the red tilapia.

\subsection{Effect of Zeolite on Growth Performance of red Tilapia}

The growth performance of red tilapia in the control treatments was calculated and recorded in Table 3. The growth performance of red tilapia in control treatments was compared with that of the zeolite. 
Table 3 Growth parameters (mean \pm SD ) of red tilapia in the control treatments under different stocking densities without zeolite

\begin{tabular}{llllll}
\hline Growth parameters & T1 & T2 & T3 & T4 & T5 \\
\hline Initial number (n) & 5 & 10 & 15 & 20 & 25 \\
Final mean number (n) & 5 & 5 & 12 & 7 & 17 \\
Mean initial weight (g) & 12.90 & 12.90 & 12.90 & 12.90 & 12.90 \\
Mean final weight (g) & 27.64 & 25.99 & 19.16 & 22.48 & 18.85 \\
Weight gain, WG (\%) & 114.26 & 101.47 & 48.53 & 74.26 & 46.12 \\
Length gain (mm) & 23.34 & 20.87 & 10.59 & 12.35 & 9.4 \\
Average daily weight gain, ADWG & 0.2340 & 0.2078 & 0.0994 & 0.1520 & 0.0944 \\
(g) & 1.12 & 1.11 & 0.63 & 0.88 & 0.6 \\
Specific growth rate, SGR (\% per day) & 100 & 50 & 80 & 35 & 68 \\
\hline Survival rate, SR (\%) & & & & & \\
\hline
\end{tabular}

The initial mean length and mean weight of fish stocked in control and zeolite groups was same. The difference between the fish in control and zeolite was not considered as significance in terms of growth performance $(p>0.05)$ when tested with MANOVA. This indicated that usage of zeolite did not influence the growth performance of red tilapia. Similar findings were found by Onder et al. who found no significant difference $(p>0.05)$ in growth performance between Tilapia zillii fed diets containing and without zeolite [31]. From the results, it was found that $\mathrm{Tl}$ with zeolite recorded the highest values in mean final weight and length, weight gain, length gain, and growth rate among the treatments. However, the mean values of these growth parameters recorded by T4 and T5 with zeolite were lower than the control. This may be due to the fact that the survival rate of the T4 and T5 with zeolite is much higher than the control. Therefore, the number of fish per unit area in the zeolite treatment was greater than that of the control. Aksungur, and Kutlu reported that high stocking densities leads to increased stress, resulting increased in energy demand and causing a reduction in growth rates and feed utilization [32]. According to Figure 2, all treatments with zeolite except T1 had higher survival rate than control. The low survival rate in $\mathrm{Tl}$ with zeolite may be due to the inhibition of proper feeding of smaller fish due to the presence of larger fish. During the experiment, it was found that one fish was much larger than the rest of the fish in the aquarium. In general, usage of zeolite did not influence the growth of red tilapia. Based on the growth performance parameters recorded in this study, it was found that red tilapia stocked in treatments with zeolite had the highest growth performance than the stocked in control treatments.

\subsection{CONCLUSION}

This research is vital to investigate the effect of stocking density on the growth performance of fish in zeolite supplemented closed system. The growth performance of red tilapia at different stocking densities in zeolite supplemented closed system was also determined. The results showed that with the increase of stocking density, the final mean length and weight showed a downward trend. It was found that fry stocked in Tl (5 fish) exhibited the highest mean final length and weight (106.33 and 40.27) while fry stocked in T5 (25 fish) recorded the lowest (87.83 and 17.26). In terms of the specific growth rate, the significantly $(p<0.05)$ highest SGR values (1.74) was recorded in $\mathrm{Tl}$ while the lowest $(0.46)$ was recorded in T5. There was a significant difference $(p<0.05)$ at different stocking density for weight gain and length gain. The length gain of red tilapia in $\mathrm{Tl}$ $(24.38 \pm 2.46)$ was significantly highest and in T5 $(5.88 \pm 2.01)$.

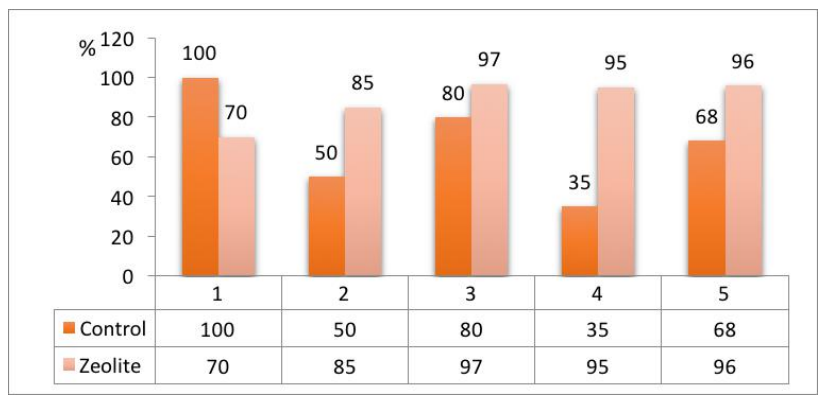

Figure 2 Comparison of survival rate (\%) between control and zeolite treatments

In this study, there was no significance ( $p>0.05)$ different in survival rate between treatments. The difference between the fish in control and zeolite was not considered as significance in terms of growth performance $(p>0.05)$ when tested with MANOVA. This indicated that usage of zeolite did not influence the growth performance of red tilapia. The results revealed that red tilapia stocked in the $\mathrm{Tl}$ of the lowest stocking density (5 fish) had the highest growth performance than the fish in other treatments. Compared to other treatments, $\mathrm{Tl}$ recorded the highest final length and weight, weight and length gain, SGR among the treatments. As conclusion, Tl with the lowest fish density is the most suitable stocking density for the red tilapia. 


\section{Acknowledgement}

The authors fully acknowledged Universiti Malaysia Kelantan and Universiti Sains Malaysia for the facilities which makes this important research viable and effective.

\section{References}

[1] Mangroves for the Future. 2009, July 1. Piloting Red Tilapia Cage Culture as an Alternative Livelihood in the Maduganga Estuary. https://www.mangrovesforthefuture.org/grants/smallgrant-facilities/sri-lanka/phase-1-projects-lk/piloting-redtilapia-cage-culture-as-an-alternative-livelihood-in-themaduganga-estuary/.

[2] Mohamad, S. N., Noordin, W. N. M., Ismail, N. F., Hamzah A. 2021. Red Hybrid Tilapia (Oreachromis spp.) Broodsttock Development in Malaysia. Status Challenges and Prospects for Future Development. Asian Fisheries Sc. 34: 73-81.

[3] Verster, N. 2017. Comparison of Growth Rates of Tilapia Species (Oreochromis Mossambicus and Oreochromis Niloticus) Raised in a Biofloc and a Standard Recirculating Aquaculture (Ras) System. Master's Thesis. Ghent University, St. Pietersnieuwstraat, Belgium.

[4] lliyasu, A., Mohamed, A. Z., Terano, R. 2016. Comparative Analysis of Technical Efficiency for Different Production Culture Systems and Species of Freshwater Aquaculture in Peninsular Malaysia. Aquacult. Rep. 3: 51-57. DOI: https://doi.org/10.1016/j.aqrep.2015.12.001.

[5] Iliyasu, A., Mohamed, Z. A. 2016. Evaluating Contextual Factors Affecting the Technical Efficiency of Freshwater Pond Culture Systems in Peninsular Malaysia: A Two-stage DEA Approach. Aquacult. Rep. 3: 12-17.

DOI: https://doi.org/10.1016/j.aqrep.2015.11.002

[6] Gupta, M. V., Acosta, B. O., 2004. A Review of Global Tilapia Farming Practices. Aquacult. IX(January 2004): 712.

[7] Ronald, N., Gladys, B., Gasper, E. 2014. The Effects of Stocking Density on the Growth and Survival of Nile Tilapia (Oreochromis niloticus) Fry at Son Fish Farm. Uganda J. Aquacult. Res. Dev. 5(222): 1-7.

[8] Daudpota, A. M., Kalhoro, I. B., Shah, S. A., Kalhoro, H. Abbas, G. 2014. Effect of Stocking Densities on Growth Production and Survival Rate of Red Tilapia in Hapa at Fish Hatchery Chilya Thatta, Sindh, Pakistan. J. of Fish. 2(3): 180-186.

DOI: https://doi.org/10.17017/jfish.v2i3.2014.45.

[9] Ani, J. S., Manyala, J. O., Masese, F. O., Fitzsimmons, K. 2021. Effect of Stocking Density on Growth Performance of Monosex Nile Tilapia (Oreochromis niloticus) in the Aquaponic System Integrated with Lettuce (Lactuca sativa). Aquacult. and Fisheries. In Press.

[10] Ghiasi, F. S. 2012. The Effects of Natural Zeolite (Clinoptilolte) on Water Quality, Growth Performance and Nutritional Parameters of Fresh Water Aquarium Fish, Angel (Pterophyllum scalare). International J. Res. in Fish. Aquacult. 2(3): 22-25.

[11] Ghasemi, Z., Sourinejad, I., Kazemian, H., Rohani, S. 2016. Application of Zeolites in Aquaculture Industry: a Review. Rev. in Aquacult. 10(1): 75-95. DOI: https://doi.org/10.1111/raq.12148.

[12] Zain, R. A. M., Shaari, N. F. I., Amin, M. F. M., Jani, M. 2018 Effects of Different Dose of Zeolite (Clinoptilolite) in Improving Water Quality and Growth Performance of Red Hybrid Tilapia (Oreochromis sp.) ARPN J. of Eng. and Appl. Sci. 13(24): 9421-9426.

[13] Zhou, L., Boyd, C. E. 2014. Total Ammonia Nitrogen Removal from Aqueous Solutions by the Natural Zeolite, mordenite: A Laboratory Test qnd Experimental Study. Aquacult. 432: 252-257.

DOI: https://doi.org/10.1016/j.aquaculture.2014.05.019.

[14] Ibrahim, A. B., Mohd Khan, A., Norrakiah, A. S., Intan Fazleen, Z. 2014. Fresh Water Aquaculture Fish Consumption in Malaysia and Heavy Metals Risk Exposure to Consumers. Int. Food Res. J. $21(6):$ 2109-2113.

[15] Yıldırım Ö.. Türker A. \& Senel B. 2009. Effects of Natural Zeolite (Clinoptilolite) Levels in Fish Diet on Water Quality, Growth Performance and Nutrient Utilization of Tilapia (Tilapia zillii) Fry. Fresenius Environ. Bull. 18(9): 1567-1571.

[16] Rafiee, G., Saad, C. R. 2006. The Effect of Natural Zeolite (clinoptiolite) on Aquaponic Production of Red Tilapia (Oreochromis sp.) and Lettuce (Lactuca sativa var. Longifolia), and Improvement of Water Quality. J. Agric. Sci. and Technol. 8: 313-322

[17] Obradovic, S., Adamovic, M., Vukasinovic, M., Jovanovic R., Levic, J. 2006. The Application Effects of Natural Zeolite in Feed and Water on Production Results of Oncorhynchus Mykiss (Walbaum). Roumanian Biotechnol. Lett. 11: 30053013

[18] Ergun, S., Tekesoglu, H., Yigit, M. 2008. Effects of Dietary Natural Zeolite Levels on Ammonia Excretion Rates in Young Rainbow Trouts (Oncorhychus mykiss). Fresenius Environ. Bull. 17: 245-248.

Faruk, M. A. R., Ali, M. M.; Patwary, Z. P. 2008. Evaluation of the Status of Use of Chemicals and Antibiotics in Freshwater Aquaculture Activities with Special Emphasis to Fish Health Management. J. Bangladesh Agric. Univ. 6: 381-390. DOI: https://doi.org/10.3329/jbau.v6i2.4838.

[19] Asgharimoghadam, A., Gharedaashi, E., Montajami, S. Nekoubin, H., Salamroudi, M., Jafariyan, H. 2012). Effect of Clinoptilolite Zeolite to Prevent Mortality of Beluga (Huso Huso) by Total Ammonia Concentration. Global Vet. 9: 8084.

https://www.cabdirect.org/cabdirect/abstract/201 23278 840.

[20] Farhangi, M., Hajimoradloo, A. M. 2011. The Effect of Zeolite (clinoptilolite) in removing Ammonia Lethal Concentration in Rainbow trout (Oncorhynchus mykiss). Iran. Sci. Fish. J. 20: 101-110.

[21] Farhangi, M., Gholipour-Kanani, H., Rostami-Charati, F. 2013. Prevention of Acute Ammonia Toxicity in Bluga (Huso huso), Using Natural Zeolite. J. of Toxicol. Environ. Health Sci. 5: 73-78.

DOI: https://doi.org/10.5897/JTEHS 11.092

[22] Ariful Islam, M., Nahid Hasan, M., Mahmud, Y., Reza, M. S.; Mahmud, M. S., Kamal, M., Siddiquee, S. 2014. Obtainable Drugs For Fish Hatchery Operation and Grow-out Ponds in Bangladesh. Annu. Res. Rev. Biol. 4: 1036-1044. DOI: https://doi.org/10.9734/ARRB/2014/7287.

[23] Sahin, D., Aral, O., Öz, M. 2016. The Effect of Natural Zeolite Clinoptilolite on Aquarium Water Conditions. Hacettepe J. Biol. and Chem. 2(44): 205-208. DOI: https://doi.org/10.15671/HJBC.20164418130.

[24] Ashraful Alam, M., Mamnur Rashid, M. 2014. Use of Aquamedicines and Chemicals in Aquaculture in Shatkhira District, Bangladesh. IOSR J. Pharm. Biol. Sci. 9: 59

[25] Chakraborty, S. B., Banerjee, S. 2010. Effect of Stocking Density on Monosex Nile Tilapia Growth during Pond Culture in India. Int. J. of Biol., Biomol. Agric. Food and Biotechnol. Eng. 4(8): 646-650

[26] Ferdous, J., Hossain, M. M., Jaman, H. U., Rupom, A. H., Tonny, N. I., Jaman, A. 2017. Psidium Guajava Leaf Extracts Fed to Mono-sex Nile Tilapia Oreochromis Niloticus Enhance Immune Response Against Pseudomonas fluorescens. Eur. J. Clin. Biomed. Sci. 3(1): 34-42.

DOI: https://doi.org/10.11648/j.ejcbs.20170301.16.

[27] Dambo, W. B., Rana, K. J. 1993. Effect of Stocking Density on Growth and Survival of Oreochromis Niloticus (L.) Fry in the Hatchery. Aquacult. Res. 24(1): 71-80.

DOI : https://doi.org/10.1111/j.1365-2109.1993.tb00829.x. 
[28] Ofor, C. O., Afia, O. E. 2015. Effect of Stocking Densities on Growth and Feed Utilization of Hybrid Catfish Effect of Stocking Densities on Growth and Feed Utilization of Hybrid Catfish (Clarias gariepinus $X$ Heterobranchus longifilis ) Fed at $1 \%$ Body Weight. Am. J. Biol. Life Sci. 3(6): 211-217.

[29] Rahman, M. 2016. Effects of Stocking Density on Growth and Production Performance of Monosex Male Tilapia (Oreochromis niloticus) in Earthen Ponds. Int. J. Fish. Aquat. Stud. 4(3): 267-271

[30] Ouattara, N., Teugels, G., Douba, V., Philippart, J. 2003. Aquaculture Potential of the Black-chinned Tilapia, Sarotherodon Melanotheron (Chiclidae): Comparative
Study of the Effect of Stocking Density on Growth Performance of Landlocked and Natural Populations Under Cage Culture Conditions in Lake Ayame (Cote d'Ivoire). Aquacult. Res. 32: 1223-1229. DOI: https://doi.org/10.1046/j.1365-2109.2003.00921.x.

[31] Onder, Y., Turker, A., Bilgin Senel. 2009. Effects of Natural Zeolite (clinoptilolite) Levels in Fish Diet on Water Quality. Growth FPerform. 18(9): 1567-1571.

[32] Aksungur, N., Akbulut, B., Kutlu, I. 2007. Effects of Stocking Density on Growth Performance, Survival and Food Conversion Ratio of Turbot (Psetta maxima) in the Net Cages on the Southeastern Coast of the Black Sea. Turkish J. Fish. Aquat. Sci. 7: 147-152. 